\title{
Tramadol does not impair the phagocytic capacity of human peripheral blood cells
}

\author{
[Le tramadol ne change pas la capacité phagocytaire des cellules du sang \\ périphérique humain]
}

Benzion Beilin md, * Galina Grinevich md, * Israel Z. Yardeni md, * Hanna Bessler phd $\dagger$

Purpose: The inhibitory effect of opioids on phagocytic cell capacity is well established. However, the effect of synthetic analgesics on this aspect of cell function is controversial. It was the aim of the study to compare the in vitro effect of tramadol with that of morphine on the engulfing ability of peripheral blood phagocytic cells from healthy volunteers.

Methods: Peripheral blood polymorphonuclear cells and monocytes from healthy volunteers were incubated with 5,10 and $20 \mu \mathrm{g} \cdot \mathrm{mL}^{-1}$ tramadol, or with 20,40 and $80 \eta \mathrm{g} \cdot \mathrm{mL}^{-1}$ morphine. To each tube, $0.05 \mathrm{~mL}$ of $5 \%$ suspension of latex beads $0.8 \mu \mathrm{m}$ in diameter was added. After incubation for $60 \mathrm{~min}$ the percentage of cells engulfing latex particles and the phagocytic index (number of particles phagocytized by each individual cell) were detected.

Results: Tramadol affected neither the percentage of cells phagocyting latex particles, nor the phagocytic index of both polymorphonuclear cells and monocytes. On the other hand, incubation with 20, 40 and $80 \eta \mathrm{g} \cdot \mathrm{mL}^{-1}$ morphine caused II\%, $14 \%$ and $24 \%$ decrease in phagocytosis $(P<0.01-P<0.00 \mathrm{I})$. The percentage of monocytes phagocyting latex particles was lower by $16 \%, 19 \%$ and $12 \%$ at the three doses tested $(P$ $<0.0 \mathrm{I}-P<0.00 \mathrm{I})$. The three doses of morphine caused a dose dependent decrease in the monocyte phagocyting index by $20 \%, 29 \%$ and $35.5 \%$ respectively $(P<0.05)$. The polymorphonuclear phagocyting index was not significantly lower following incubation with the drug $(P=0.053)$.

Conclusion: The lack of noxious effect of tramadol on the engulfing capacity of phagocytic cells suggests additional benefit to the relatively safe profile of the drug.
Objectif : L'effet inhibiteur des opioïdes sur la capacité des cellules phagocytaires est bien établi. Mais l'effet des analgésiques synthétiques est controversé. Nous voulions comparer l'effet in vitro du tramadol et de la morphine sur la capacité d'englobage que possèdent les cellules sanguines phagocytaires périphériques prélevées chez des volontaires sains.

Méthode : Des polynucléaires et des monocytes ont été prélevés dans le sang périphérique de volontaires sains et incubés avec 5, 10 et $20 \mu \mathrm{g} \cdot \mathrm{mL}^{-1}$ de tramadol, ou 20,40 et $80 \mathrm{\eta g} \cdot \mathrm{mL}^{-1}$ de morphine. À chaque tube, $0,05 \mathrm{~mL}$ d'une suspension à $5 \%$ de particules de latex de 0,8 $\mu \mathrm{m}$ de diamètre a été ajouté. Après 60 min d'incubation, le pourcentage de cellules ayant englobé les particules de latex et l'indice phagocytaire (nombre de particules phagocytées par chaque cellule) ont été détectés.

Résultats : Le tramadol n'a pas modifié le pourcentage de cellules qui ont phagocyté les particules de latex, ni l'indice phagocytaire des polynucléaires et des monocytes. L'incubation avec 20, 40 et $80 \mathrm{ng} \cdot \mathrm{mL}^{-1}$ de morphine a réduit la phagocytose de II \%, $14 \%$ et $24 \%(P<0,0 I-P<0,00 I)$. Le pourcentage de monocytes englobant les particules de latex a baissé de 16 $\%, 19 \%$ et $12 \%$ pour les trois doses testées $(P<0,01-P$ $<0,001)$. Les trois doses de morphine ont causé une baisse en fonction de la dose de l'indice phagocytaire des monocytes, soit respectivement de $20 \%, 29 \%$ et 35,5\% $(P<0,05)$. L'indice phagocytaire des polynucléaires n'était pas significativement plus bas à la suite de l'incubation avec le médicament $(P=0,053)$. Conclusion : L'absence d'effet nuisible du tramadol sur la capacité des cellules phagocytaires à englober des corps étrangers solides ajoute un avantage possible au profil relativement sécuritaire de ce médicament.

From the Department of Anesthesiology, ${ }^{*}$ and the Laboratory for Immunology and Hematology Research, $†$ Rabin Medical Centre, Golda Campus (Hasharon), Petah Tiqva, and The Sackler School of Medicine, Tel-Aviv University Ramat Aviv, Israel.

Address correspondence to: Dr. Benzion Beilin, Department of Anesthesia, Rabin Medical Centre, Golda Campus (Hasharon), 7 Keren

Kayemet St., Petah Tiqva, 47372, Israel. Phone: 972-3-9372469; Fax: 972-3-9372470:E-mail: beilinb@clalit.org.il

The study was supported by department sources.

Assessed April 11, 2005.

Accepted for publication July 4, 2005.

Revision accepted July 11, 2005. 
$\mathrm{T}$ HE capacity of the peripheral blood phagocytes, namely polymorphonuclear cells and monocytes, to engulf microorganisms plays an important role in the immune defense of the organism. This cell function is not limited to extraction and killing pathogens only, but it is extended to removal of damaged and apoptotic cells, yeasts and even inert particles such as latex beads. ${ }^{1}$ However, like any other frontline defenders, phagocytes are vulnerable and face the risk of injuries by toxins, oxidants, chemicals and especially drugs that might impair their engulfing capacity. Patients scheduled to undergo surgical interventions are exposed to a substantial number of analgesics during the pre- and postoperative periods. Since their immune system is often compromised by perioperative stress, ${ }^{2}$ any further impairment of the peripheral blood cell phagocytic function by administration of analgesics may serve as a predisposing factor for infections. Therefore, it is of great importance for both anesthesiologists and surgeons to understand the effect of analgesics on the phagocytic function of the peripheral blood cells. One widely used opioid analgesic is tramadol, a synthetic derivate of codeine indicated for management of acute and chronic pain in both hospitals and outpatient clinics. The drug is a centrally acting analgesic that relieves pain through synergistic monoaminergic and $\mu$-opioid mechanisms. ${ }^{3}$ It possesses a good safety profile, it is rapidly absorbed in the upper small intestine, metabolized in the liver and excreted mainly by the kidneys. The pharmacokinetics, pharmacology, adverse effects and clinical use guidelines of the drug have been reviewed in detail by Duthie ${ }^{4}$ and Shipton. ${ }^{5}$ Since it is well established that opioids modulate immune responses including an inhibitory effect on phagocytosis, ${ }^{6-9}$ the aim of the present study was to compare the in vitro effect of tramadol with that of morphine on the engulfing capacity of peripheral blood phagocytic cells from healthy volunteers.

\section{Methods \\ Cell preparation and culture conditions}

Thirty healthy volunteers, members of the Department of Anesthesiology staff, were included in the study after providing written informed consent. Leukocyte rich plasma was obtained from heparinized peripheral venous blood by centrifugation at $800 \mathrm{rpm}$ for ten minutes. The cells were counted and suspended at a concentration of 2 $\times 10^{6}$ in autologous plasma.

\section{Phagocytosis}

Aliquots of cell suspension $(0.95 \mathrm{~mL})$ were incubated with 5,10 and $20 \mu \mathrm{g} \cdot \mathrm{mL}^{-1}$ of tramadol (tramadol hydro- chloride, Grunenthal GmbH, Aachen, Germany) or with 20, 40 and $80 \eta \mathrm{g} \cdot \mathrm{mL}^{-1}$ of morphine (morphine sulfate, Rafa, Jerusalem, Israel). In one set of experiments, cells were incubated with both $5 \mu \mathrm{g} \cdot \mathrm{mL}^{-1}$ tramadol and 20 $\eta \mathrm{g} \cdot \mathrm{mL}^{-1}$ morphine. The dosage of the drugs used in the study was extrapolated from therapeutic concentrations. To each tube, $0.05 \mathrm{~mL}$ of $5 \%$ suspension of latex beads $0.8 \mu \mathrm{m}$ in diameter (Sigma, Rohovot, Israel) was added. Incubation was carried on for $60 \mathrm{~min}$ at $37^{\circ} \mathrm{C}$ in a humidified atmosphere containing $5 \% \mathrm{CO}_{2}$. Cells incubated without any drug served as controls. Following incubation, the cells were sedimented by centrifugation, washed twice in phosphate buffered saline, smeared on glass slides and stained using the May Grünwald-Giemsa method. The percentage of phagocyting cells and the number of latex particles engulfed by each individual cell (phagocytic index) were detected. At least 100 polymorphonuclear cells and monocytes were counted for each experimental point.

\section{Statistical analysis}

The data were evaluated using repeated measures analysis of variance; post-hoc Bonferroni's correction was applied as appropriate to adjust for multiple comparisons. Results are expressed as mean \pm SEM. The level of significance was established at a $P$ value $<0.05$.

\section{Results}

The percentage of phagocyting cells incubated with tramadol did not differ from that of the controls. Similarly, the drug did not affect the phagocytic index of either polymorphonuclears or monocytes (Figure).

Incubation with morphine was associated with a significant inhibitory effect on the engulfing capacity of both polymorphonuclear cells $\left(\mathrm{F}_{(3,48)}=12.05, P<0.001\right)$ and monocytes $\left(\mathrm{F}_{(3,48)}=4.442, P<0.03\right)$. Doses of 20, 40 and $80 \eta \mathrm{g} \cdot \mathrm{mL}^{-1}$ of morphine caused $11 \%, 14 \%$ and $24 \%$ inhibition of polymorphonuclears' engulfing capacity $(P$ $<0.01-P<0.001)$. The percentage of monocytes phagocyting latex particles was lower by $16 \%, 19 \%$ and $12 \%$ at the three doses tested $(P<0.01-P<0.001)$.

Following incubation with morphine, the polymorphonuclear phagocyting index was not significantly reduced $\left(\mathrm{F}_{(3,46)}=2.794, P=0.113\right)$, whereas that of monocytes was numerically less but not significantly different from preincubation values $\left(\mathrm{F}_{(3,47)}=2.715, P=0.06\right)$. Incubation with 20, 40 and $80 \eta \mathrm{g} \cdot \mathrm{mL}^{-1}$ of morphine was associated with a dose dependent decrease in the monocyte phagocyting index by $20 \%, 29 \%$ and $35.5 \%$ respectively $(P<$ $0.05)$. Incubation of polymorphonuclears or monocytes with both $5 \mu \mathrm{g} \cdot \mathrm{mL}^{-1}$ tramadol and $20 \eta \mathrm{g} \cdot \mathrm{mL}^{-1}$ of morphine decreased the percentage of polymorphonuclears and monocytes capable for phagocytosis by $15 \%$ and 

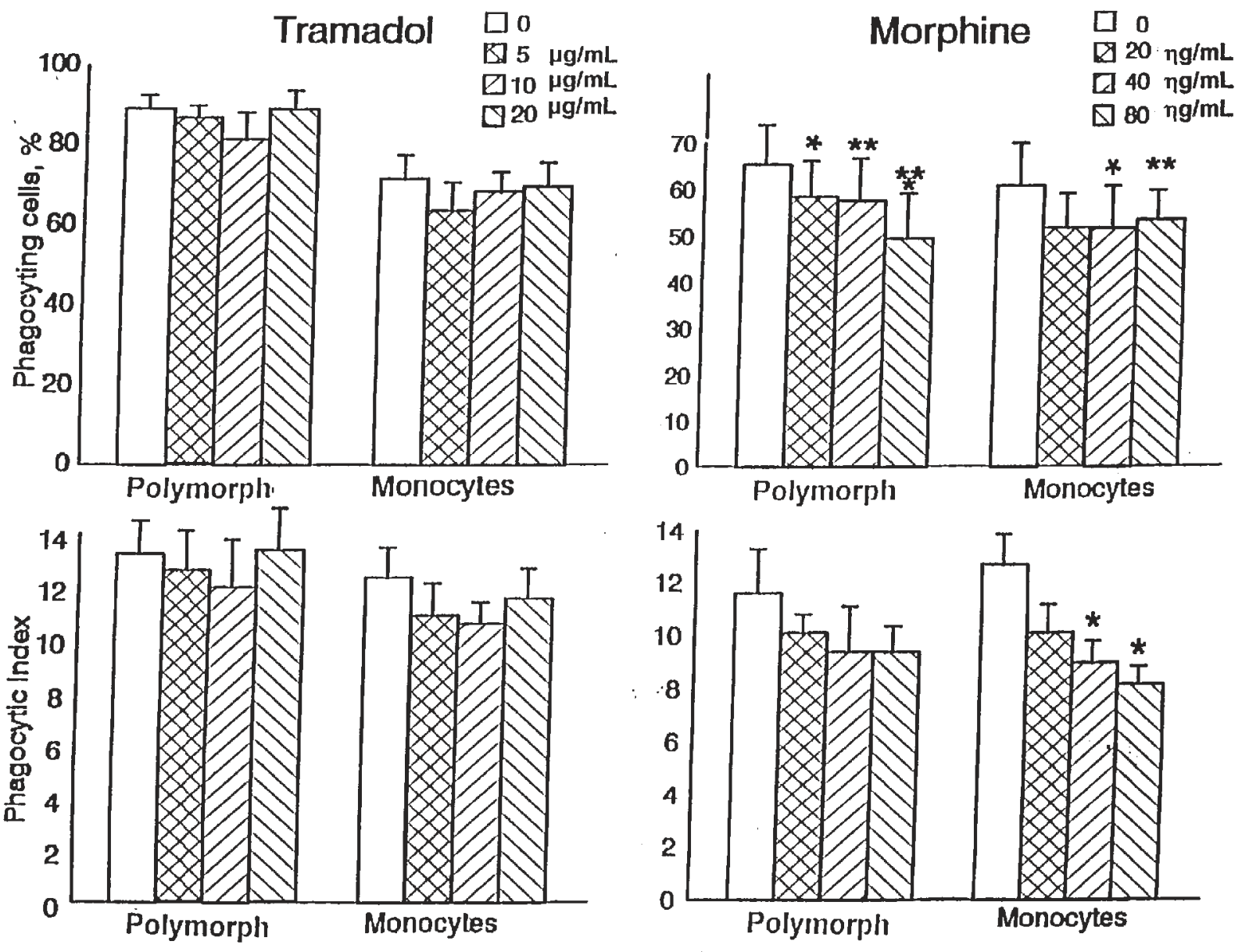

FIGURE Effect of tramadol and morphine on the phagocytic capacity and phagocytic index of human peripheral blood polymorphonuclears and monocytes. Tramadol did not affect any of these functions. Incubation with morphine caused a significant dose-dependent inhibition of both types of cells, but affected the phagocytic index of the monocytes only. Bars represent SEM. ${ }^{*} P<0.05 ;{ }^{*} P<0.01 ;{ }^{*}{ }^{*} P<0.001$.

$19 \%$ respectively $(P<0.02$ and $P<0.002)$. However, the phagocytic index of both cell types did not differ from the values obtained when the cells were incubated separately with each drug.

\section{Discussion}

The observation that anesthetics may affect the function of the phagocytic cells has been well established. Krumholz et al. ${ }^{10,11}$ have shown that incubation of polymorphonuclear cells with midazolam, droperidol, thiopentone, etomidate, ketamine and flunitrazepam inhibits their phagocytic and killing capacity of human pathogens. On the other hand, Davidson et al. ${ }^{12}$ reported that ketamine and thiopentone may affect the phagocytic function of polymorphonuclear cells only at higher than clinically relevant doses. It is of interest that while most of these drugs inhibited the phagocytosis of E. coli and paraffin oil droplets, propofol, midazolam and ketamine do not affect phagocytosis of Staph. Aureus. ${ }^{2,13}$ Since the administration of anesthetics is relatively short in time compared to the use of analgesics during the postoperative period, it is expected that the function of peripheral blood phagocytes will be at an increased risk under the influence of pain relieving drugs.

The present study shows that incubation of human peripheral blood phagocytic cells with increasing doses of tramadol affected neither the percentage of 
cells capable of phagocytosis, nor their phagocytic index. On the other hand, incubation with morphine induced a dose-dependent decrease in phagocytic capacity of both polymorphonuclears and monocytes. It is of interest that incubation with $5 \mu \mathrm{g} \cdot \mathrm{mL}^{-1}$ of tramadol and $20 \mathrm{~g} \cdot \mathrm{mL}^{-1}$ of morphine caused a slight but significant increase in the phagocytic capacity of both polymorphonuclears and monocytes. Although their phagocytic index was not affected, this observation suggests an additive effect of these drugs on phagocyte engulfing ability.

Opiates and opioids have been shown to interact with the immune system ${ }^{14}$ and their suppressive effect on the phagocyte engulfing capacity has been well documented in a large number of publications. ${ }^{9,14-17}$ There are several studies attempting to elucidate the mechanism by which opiates alter the engulfing capacity of the phagocytic cells. According to Makman et al. ${ }^{18}$ human granulocytes possess a morphine-sensitive $\mu 3$-receptor subtype that mediates a suppressive effect of the drug on the cell phagocytic capacity. It has been shown that naloxone is able to block this effect. ${ }^{17,18}$ Similarly, tramadol binds to $\mu$-opioid receptors, but with low affinity. ${ }^{19}$ Investigations carried out by Tomei $e t a l{ }^{15}$ suggest that the effect of morphine on murine macrophages depends on several factors, such as concentration and exposure time, a fact that may explain the biphasic dose-response curve of the cells to the drug expressed either as inhibition or stimulation of their phagocytic capacity. ${ }^{20}$ Another possibility is that morphine affects phagocytosis by inducing changes in cell membrane fatty acid composition causing a decrease of its fluidity, which in turn will impair formation of pseudopodia and internalization of pathogens and foreign particles. A decrease in membrane fluidity of the blood-brain barrier tissue due to alteration in cell membrane fatty acid composition has been shown in rabbits following tramadol administration. ${ }^{21}$ However, this mechanism would be unlikely to explain the findings in our study, since we did not observe impaired phagocytosis after incubation of peripheral blood phagocytic cells with tramadol, at least with the doses used. Based on observations that applied in analgesic doses, tramadol and morphine exert different immune responses in both humans and rodents. Concomitant with a reciprocal effect on natural killer cell activity, ${ }^{19,22,23}$ it is conceivable that the outcome regarding the engulfing function of the phagocytic cells will proceed through different pathways. Moreover, and in contrast to other opioids, the analgesic action of tramadol is only partially inhibited by the opioid antagonist naloxone, which suggests the existence of another mechanism of action. The inhibi- tory effect of opioids on the function of the immune cells and especially on phagocytosis may explain the increased susceptibility to infections in addicts, though this effect has been shown to be reversible. ${ }^{24}$

In conclusion, the present study shows that incubation of human peripheral blood phagocytic cells with increasing doses of tramadol did not affect their engulfing capacity for latex particles, while this cell function was dose-dependently impaired following incubation with morphine. This observation may be of particular clinical relevance in the selection of anesthetic drugs for immunocompromised patients.

\section{References}

1 Djaldetti M, Salman H, Bergman M, Djaldetti R, Bessler $H$. Phagocytosis - the mighty weapon of the silent warriors. Micros Res Tech 2002; 57: 421-31.

2 Galley HF, DiMatteo MA, Webster NR.

Immunomodulation by anaesthetic, sedative and analgesic agents: does it matter? Intensive Care Med 2000; 26: 267-74.

3 Fricke JR Jr, Hewitt DJ, Jordan DM, Fisher A, Rosenthal NR. A double-blind placebo-controlled comparison of tramadol/acetaminophen and tramadol in patients with postoperative dental pain. Pain 2004; 109: 250-7.

4 Duthie DJ. Remifentanil and tramadol. Br J Anaesth 1998; 81: 51-7.

5 Shipton EA. Tramadol-present and future. Anaesth Intensive Care 2000; 28: 363-74.

6 Szabo I, Rojavin M, Bussiere JL, Eisenstein TK, Adler $M W$, Rogers TJ. Suppression of peritoneal macrophage phagocytosis of Candida albicans by opioids. J Pharmacol Exp Ther 1993; 267: 703-6.

7 Rojavin M, Szabo I, Bussiere JL, Rogers TJ, Adler MW, Eisenstein TK. Morphine treatment in vitro or in vivo decreases phagocytic functions of murine macrophages. Life Sci 1993; 53: 997-1006.

8 Hamra JG, Yaksh TL. Equianalgesic doses of subcutaneous but not intrathecal morphine alter phenotypic expression of cell surface markers and mitogen-induced proliferation of rat lymphocytes. Anesthesiology 1996; 85: 355-65.

9 Eisenstein TK, Hilburger ME. Opioid modulation of immune responses: effects on phagocyte and lymphoid cell populations. J Neuroimmunol 1998; 83: 36-44.

10 Krumbolz W, Endrass J, Knecht J, Hempelmann G. The effect of midazolam, droperidol, fentanyl, and alfentanil on phagocytosis and killing of bacteria by polymorphonuclear leukocytes in vitro. Acta Anaesthesiol Scand 1995; 39: 624-7.

11 Krumbolz W, Endrass J, Hempelmann G. Inhibition of phagocytosis and killing of bacteria by anaesthetic 
agents in vitro. Br J Anaesth 1995; 75: 66-70.

12 Davidson JA, Boom SJ, Pearsall FJ, Ramsay G.

Comparison of the effects of four i.v. anaesthetic agents on polymorphonuclear leucocyte function. $\mathrm{Br} \mathrm{J}$ Anaesth 1995; 74: 315-8.

13 Jensen AG, Dablgren C, Eintrei C. Propofol decreases random and chemotactic stimulated locomotion of human neutrophils in vitro. Br J Anaesth 1993; 70: 99-100.

14 Sacerdote P, Manfredi B, Mantegazza P, Panerai AE. Antinociceptive and immunosuppressive effects of opiate drugs: a structure-related activity study. $\mathrm{Br} \mathrm{J}$ Pharmacol 1997; 121: 834-40.

15 Tomei EZ, Renand FL. Effect of morphine on Fc-mediated phagocytosis by murine macrophages in vitro. J Neuroimmunol 1997; 74: 111-6.

16 Welters ID, Menzebach A, Goumon $\Upsilon$, et al. Morphine suppresses complement receptor expression, phagocytosis, and respiratory burst in neutrophils by a nitric oxide and $\mu_{3}$ opiate receptor-dependent mechanism. J Neuroimmunol 2000; 111: 139-45.

17 Kobnke A, Maier C, Palm S, Barth J. In vitro investigations of the effect of morphine and its metabolites on the phagocytosis of peripheral mononuclear cells (German). Schmerz 1999; 13: 121-6.

18 Makman MH, Bilfinger TV, Stefano GB. Human granulocytes contain an opiate alkaloid-selective receptor mediating inhibition of cytokine-induced activation and hemotaxis. J Immunol 1995; 154: 1323-30.

19 Sacerdote P, Bianchi M, Gaspani L, et al. The effects of tramadol and morphine on immune responses and pain after surgery in cancer patients. Anesth Analg 2000; 90: 1411-4.

20 Pacifici R, Patrini G, Venier I, Parolaro D, ZuccaroP, Gori E. Effect of morphine and methadone acute treatment on immunological activity in mice: pharmacokinetic and pharmacodynamic correlates. J Pharmacol Exp Ther 1994; 269: 1112-6.

21 Alici HA, Ozmen I, Cezur M, Sahin F. Effect of the spinal drug tramadol on the fatty acid compositions of rabbit spinal cord and brain. Biol Pharm Bull 2003; 26: 1403-6.

22 Sacerdote P, Bianchi $M$, Manfredi B, Panerai AE. Effects of tramadol on immune responses and nociceptive thresholds in mice. Pain 1997; 72: 325-30.

23 Gaspani L, Bianchi M, Limiroli E, Panerai AE, Sacerdote $P$. The analgesic drug tramadol prevents the effect of surgery on natural killer cell activity and metastatic colonization in rats. J Neuroimmunol 2002; 129: 18-24.

24 Lazaro MI, Tomassini N, Gonzalez I, Renand FL. Reversibility of morphine effects on phagocytosis by murine macrophages. Drug Alcohol Depend 2000; 58: $159-64$. 